\title{
CHARACTERIZATION OF MATERIALS FOR POROUS CELLULAR CERAMIC USING LAMP GLASS RESIDUE IN ITS COMPOSITION
}

\author{
V.S. Porto ${ }^{1}$;A.M.B. Araujo ${ }^{2}$;C.R.S. Morais ${ }^{1}$; M.S.L. Cavalcanti ${ }^{3}$ \\ ${ }^{1}$ Academic Unit of Materials Engineering - CCT - UFCG \\ ${ }^{2}$ Post Graduation Program on Process Engineering-UFCG \\ ${ }^{3}$ Department of Basic and Social Sciences- CCHSA-UFPB \\ *Corresponding author's email: valdeniaporto@gmail.com
}

The social concern for the environment has been progressively increasing over the years. The population in general has started paying attention to the concepts of sustainability, various segments related to science and technology are looking for alternatives to control or minimize the damage caused by indiscriminate consumption of raw materials and energy, in addition to the high volume of waste generated. In this perspective, the objective of this research was to study the possibility of using fluorescent lamp glass waste, partially replacing the clay in proportions of $5 \%, 7 \%$ and $10 \%$, a composition of porous ceramic cell, to obtain products having properties that are similar to traditional properties, and also the possibility of directing the reuse of this type of waste. The raw materials were characterized by the following tests: Spectroscopy Dispersive Energy X-ray (EDX), Granulometric Analysis, X-Ray Diffraction (XRD). The results showed that the fluorescent glass residue displayed a similar silica content compared to the amount found in clay. There was also a wide particle size distribution, which will contribute to a good packing of the particles, and clay minerals that specifically come from the raw materials that are being studied. These results enable the use of fluorescent lamp glass residue in the composition of porous cellular ceramic.

Keywords: porous ceramic; recycling ; fluorescent lamp residue, materials characterization;

\section{INTRODUCTION}

The interest of brazilian society related to environmental issues and the acknowledgement of the importance of this matter to everyone's future. As a proof of this, there was the approval of law number 12.305, on August 2, 2010, a significant advance in brazilian environmental policy. The new legislation created more comprehensive guidelines for the management of solid waste and, therefore, it can be understood as a feedback from many demands that were made in the past, not only by environmentalists, but also by society in general, about the exponential accumulation of waste in urban and rural areas ${ }^{(1)}$.
According to the recycler Ambiensys (2011), approximately $95 \%$ of the lamps recycling users are in commerce, industry and services, only $5 \%$ are residential. Also, only $6 \%$ of the lamps that are discarded pass through a recycling process.

The processes that analyze the possibilities of the use of glass waste in ceramics are under studied. The reuse of such wastes in ceramic foams presents an interesting application, since it provides raw materials savings, as well as offers an ecologically correct destination for this kind of waste.

Pokorny (2011) analyzed glass foams for application of insulating produced from waste glass coming from transparent glass packages, and a synthetic carbonate, used as foaming agent. The results showed that glass foams can be obtained from glass powder, using a synthetic carbonate, and the introduction of different oxides as foaming agents.

Facing the environmental problems caused by the disposal of glass waste in the open, this research aims to analyze the use of lamp glass waste in the composition of cellular porous ceramic using glassy residue in its composition. This analysis can bring environmental benefits by redirecting these residues for this purpose.

\section{MATERIALS AND METHODS}

The following traditional raw materials were used in this work: clay e alumina, donated by COTEBRAS (Companhia Tecnocerâmica do Brasil) company. The glass residues were benefited using a sieve, so that they could be characterized. The fluorescent lamp glass residue was provided - as a donation - by an industry of Ceará.

This residue was received in the form of shards, which was used by the supplier company, and they went through a decontamination process, using a device called "Papa-lamps", which removes the mercury vapor residue.

So that it was possible to obtain the smallest fragments from the fluorescent lamp glass residue, it was needed to use a mortar and a pestle, and after that, these fragments were milled in parakeet mill, for approximately 30 minutes to be transformed into a powder, and after, processed in a mesh to 200 mesh so that it was possible to perform the characterization of it.

\section{A. The Characterization of Raw Materials}

All characterizations were performed at the Laboratory of Characterization from the Academic Unit of Materials 
Engineering at Federal University of Campina Grande (UFCG).

\section{Spectroscopy Dispersive Energy X-ray (EDX)}

To identify the chemical composition (oxides that are present) of the raw materials and the waste glass, lozenges were pressed at 5 tons per 30 seconds, so that they could be placed on the Shimadzu Fluoreccence X-ray Spectrometer (EDX 720).

\section{Granulometric Analysis}

To perform the test, the equipment used was the CILAS 1064, with the particle size distribution by laser diffraction method, and the analysis was carried out in aqueous environment at a rationale of $250 \mathrm{ml}$ of distilled water to $5 \mathrm{~g}$ of each material.

\section{X-Ray Diffraction (XRD)}

To characterize the raw materials through the X-ray diffraction equipment SHIMADZU XRD - 6000 was needed $\mathrm{CuK} \alpha$ radiation, voltage $40 \mathrm{kV}$, current of $30 \mathrm{~mA}$, with a $0,02^{\circ}$ step and counting time of $0.6 \mathrm{~s}$, with scan 2 to $60^{\circ}$, using the system $\theta-2 \theta$ and "Fixed Time" reading mode.

\section{RESULTS AND DISCUSSION}

Table 1 presents the chemical composition of the raw materials used, obtained by energy dispersive spectroscopy Xray $(\mathrm{EDX})$, expressed as oxides.

Table 1 - Chemical composition of raw materials

\begin{tabular}{c|c|c|c|l|l|l|l|l}
\hline \multirow{2}{*}{$\begin{array}{c}\text { RAW } \\
\text { MATERIALS }\end{array}$} & \multicolumn{7}{|c}{ CONCENTRATIONS (\%) } \\
\cline { 2 - 9 } & $\mathrm{SiO}_{\mathbf{2}}$ & $\mathrm{Al}_{\mathbf{2}} \mathrm{O}_{\mathbf{3}}$ & $\mathrm{K}_{\mathbf{2}} \mathrm{O}$ & $\mathrm{CaO}$ & $\mathrm{Fe}_{\mathbf{2}} \mathrm{O}_{\mathbf{3}}$ & $\mathrm{TiO}_{\mathbf{2}}$ & $\mathrm{Na}_{\mathbf{2}} \mathrm{O}$ & Outros \\
\hline Clay & 57,43 & 37,31 & 0,79 & 0,25 & 1,39 & 1,23 & - & 1,60 \\
\hline Alumina & 0,46 & 99,33 & - & 0,064 & 0,034 & - & - & 0,11 \\
\hline $\begin{array}{c}\text { Fluorescent } \\
\text { glass waste }\end{array}$ & 64,95 & 4,31 & 1,10 & 5,26 & 0,10 & - & 19,53 & 4,75 \\
\hline
\end{tabular}

From the results shown in Table 1, it appears that the clay had typical composition of the "Ball Clay", rich in silica and alumina, with much lower levels of titanium oxides, calcium and potassium $\left(\mathrm{TiO}_{2}, \mathrm{CaO}, \mathrm{K}_{2} \mathrm{O}\right)$.

The alumina showed a predominance of aluminium oxide in its composition $(99,33 \%)$, with only traces of other oxides. The presence of $\mathrm{SiO} 2, \mathrm{CaO}$ and $\mathrm{Fe} 2 \mathrm{O} 3$ is associated with impurities that are present in the raw material. Such values corroborate Menezes et al (2010).

The waste lamp glass presented $64.95 \%$ of $\mathrm{SiO} 2 ; 4.31 \%$ of $\mathrm{Al} 2 \mathrm{O} 3$ and percentage of calcium oxide $(\mathrm{CaO})$ of $5.26 \%$ and sodium $\left(\mathrm{Na}_{2} \mathrm{O}\right)$ of $19.53 \%$, which are characteristic amounts of soda-lime glass.

According to Morais (2013) in a fluorescent lamp glass bulb, we usually find a consistent chemical composition to the standard composition for soda-lime glass $\left(\mathrm{SiO}_{2}-73 \% ; \mathrm{Al}_{2} \mathrm{O}_{3}-\right.$ $1 \%, \mathrm{Na}_{2} \mathrm{O}-17 \%, \mathrm{MgO}-4 \%$ and $\mathrm{CaO}-5 \%$ ).
Table 2 presents values of particle size distribution of the clay, alumina and the vitreous residue, as shown respectively.

Table 2 -Particle size distribution of raw materials

\begin{tabular}{|c|c|c|c|c|c|c|c|}
\hline SAMPLES & $\begin{array}{c}\text { Fine } \\
(x<2 \mu \mathrm{m})\end{array}$ & $\begin{array}{c}\text { Medium } \\
(2 \mu \mathrm{m}<x<20 \mu \mathrm{m})\end{array}$ & $\begin{array}{c}\text { Coarse } \\
(x>20 \mu m)\end{array}$ & $\begin{array}{c}D_{10} \\
(\mu \mathrm{m})\end{array}$ & $\begin{array}{c}D_{50} \\
(\mu \mathrm{m})\end{array}$ & $\begin{array}{c}\mathrm{D}_{90} \\
(\mu \mathrm{m})\end{array}$ & $\begin{array}{c}D_{m} \\
(\mu \mathrm{m})\end{array}$ \\
\hline Clay & 23,37 & 67,53 & 9,07 & 1,01 & 4,62 & 18,79 & 7,79 \\
\hline Alumina & 1,55 & 0,94 & 97,51 & 54,41 & 88,81 & 127,63 & 89,28 \\
\hline $\begin{array}{l}\text { Waste lamp } \\
\text { glass }\end{array}$ & 1,97 & 20,16 & 79,84 & 8,23 & 50,40 & 66,23 & 102,74 \\
\hline
\end{tabular}

The alumina showed the largest average size $(89.29 \mathrm{mM})$, clay $(7.79 \mathrm{mM})$ and the glass residue $(102.75 \mathrm{mM})$. Showing a well diversified size distribution, that is usually desirable, since in ceramics, to get a good packaging, smaller particles shall occupy the spaces left empty by larger particles.

The Figure 1 presents the XRD patterns of alumina, clay and glassy residue.

Figure 1 - X-ray diffractogram of raw materials

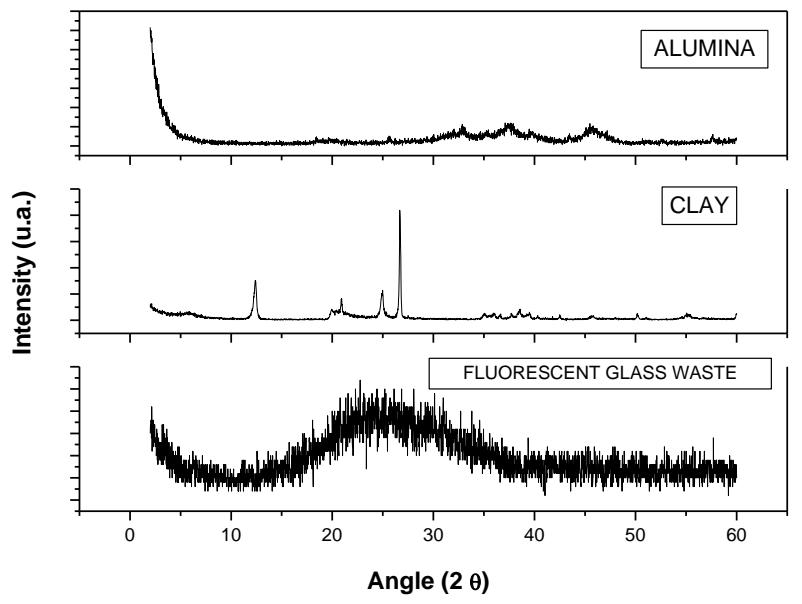

In Figure 1 we can confirm the presence of clay minerals and high kaolinite content proving favoring the use of these substances are shown in white ceramic. The kaolinite peaks are very characteristic, and have interplanar distances of 7,10, 4,43, 3,54, 3,32 and 2,32 A. Those distances simply indicate that the material that's being studied comes from kaolinite, and those results corroborate Albers et al (2012).

Inside the diffractogram from the alumina, is possible to see that there is a predominance of the crystal phase $\mathrm{Al} 2 \mathrm{O} 3$, with peaks that are very characteristic from this specific phase. This result is not a surprise, since this material has a $99,33 \%$ purity percentage approximately, which was observed in the spectroscopy dispersive energy X-ray (EDX), revealing that $\mathrm{Al}_{2} \mathrm{O}_{3}$ was characterized as the most stable form of this oxide. These results are according to Barbosa et al (2010).

As it is possible to notice from the diffractometric curve from the lamp glass residue on Figure 4.6, we observed that there are no crystal phases, as the material itself has no form. There is a band that is about $25^{\circ}$, and it's from the presence of silica in the sample, which confirms the studies performed by Kruger (2013). 


\section{CONCLUSIONS}

With this study of addition of lamp glass waste in a porous ceramic cellular mass, we concluded that:

- Through the study of energy dispersive of X-ray spectroscopy (EDX) was verified that the clay showed typical composition for this material, that is rich in silica and alumina. The electro fused alumina showed a predominance of aluminum oxide and the lamp glass residue presented characteristic amounts of sodium calcium glass.

- Through the granulometric study it is possible to verify the distributions of the particles used in this research, being possible to observe that there is a large distribution, and we assume that this will contribute to a much better packing of the particles, which most likely will provide great mechanical properties to the final product.

- Through the XRD patterns of the samples, it was found that the results showed peaks and characteristic bands for each material, which in this case are clay, electro fused alumina and lamp glass waste.

\section{REFERENCES}

[1] PEREIRA, J. A. R., Geração de Resíduos Industriais e Controle Ambiental. Available at: <www.desenvolvimento.gov.br> Accessed on: July, 7, 2012.

[2] AMBIENSYS, O lucrativo filão de reciclar lâmpadas. Available at: <http://www.bulbox.com.br/news_02_03_07.html> Accessed on: November, 15, 2011.

[3] POKORNY, A.; VICENZI, J. ; BERGMANN, C.P. Influência da Granulometria das Matérias-Primas na Microestrutura e nas Propriedades de Espumas Vítreas. Congresso SAM/CONAMET. San Nicolás, Septiembre de 2007.

[4] MORAIS, A.S.C.; MONTEIRO, S.N. ;ALEXANDRE, J; XAVIER, G.C.;VIEIRA, C.M.F. Caracterização de resíduo de lâmpada fluorescente para incorporação em cerâmica vermelha. Revista da Anicer - n ${ }^{\circ}$ 81, 2013.

[5] ALBERS, P. F.; MELChIADES, F. G.; MACHADO, R.; BALDO, J. B.; BOSCHI, A. O. Um método simples de caracterização de argilominerais por difração de raios X. Cerâmica vol.48 $\mathrm{n}^{\circ} .305$. São Paulo Jan./Feb./Mar. 2002.

[6] BARbosa L. B., Jesus L. M., MAtOS S. J., MACEDO Z. S. Produção de espuma cerâmica com baixo impacto ambiental para aplicação em petróleo. Departamento de Física, Universidade Federal de Sergipe, Campus Universitário, São Cristóvão. Dezembro, 2010.

[7] KRUGER, F.R.; OLIVEIRA, D.L.A.; Braga, S.R.O.Q. Incorporação de vidro plano moído em substituição ao cimento e ao agregado miúdo (areia) em argamassas de concreto. Available at: < http://www.sec.sbq.org.br>. Accessed on: August, 25, 2013. 